\title{
Seed desiccation tolerance and dormancy of three endangered New Zealand species: Carmichaelia williamsii, Clianthus puniceus and Hibiscus diversifolius
}

\author{
M.J. PARK ${ }^{1,3}$, C.R. MCGILL ${ }^{1}$, W.M. WILLIAMS ${ }^{2}$ and B.R. MACKAY ${ }^{1}$ \\ ${ }^{1}$ Institute of Natural Resources, College of Sciences, Massey University, Private Bag 11-222, Palmerston North, \\ New Zealand \\ ${ }^{2}$ Margot Forde Forage Germplasm Centre, AgResearch Grasslands, Private Bag 11-008, Palmerston North, New Zealand \\ ${ }^{3}$ Korea Seed \& Variety Service, Anyang-Si Gyeonggi-do, Republic of Korea \\ myoungjoo.park.1@uni.massey.ac.nz
}

\begin{abstract}
At least one third of New Zealand's indigenous plant species are threatened with extinction and strategies for conserving endangered flora are urgently required. One strategy is to use ex situ seed storage as a complement to in situ conservation. Successful ex situ storage of seed requires knowledge of the seed storage behaviour, optimal storage conditions and germination requirements of the species being stored. For many threatened species, however, this information is either incomplete or unavailable. In this study, preliminary experiments were conducted with three threatened species, Carmichaelia williamsii, Clianthus puniceus and Hibiscus diversifolius, to determine their desiccation tolerance and dormancy status. Seeds were tested for germination following desiccation and dormancy-breaking treatment. Seeds of all three species could be dried to moisture contents of $2.9-3.7 \%$ without losing viability. All three species became predominantly hardseeded at approximately $10 \%$ moisture content. However, $C$. puniceus became permeable to water again at moisture contents below $6 \%$. In all species, manual scarification of seeds improved germination to $96-100 \%$ compared with $5-20 \%$ in untreated seeds. Dormancy in these species is a function of the seed coat preventing water uptake by the dry seed. While seeds of these species are most likely desiccation tolerant and thus can potentially be stored for long periods under
\end{abstract}

conventional conditions, the loss of dormancy of $C$. puniceus at very low moisture contents is of concern. More work is needed to confirm the long-term storage behaviour of these species.

Keywords: ex situ conservation, seed storage behaviour, New Zealand flora

\section{Introduction}

New Zealand possesses a unique and diverse flora of 2,300-2,470 taxa, with most species (80\%) being endemic (Dopson et al. 1999). Currently $34 \%$ of these taxa are classified as threatened or naturally uncommon, with 11 presumed to be extinct (Warmington et al. 1996; de Lange et al. 2004). In order to combat further species loss, a range of conservation solutions including both in situ protection and restoration and $e x$ situ conservation is required.

In situ conservation aims to conserve species within their natural habitat by managing that habitat in a sustainable way. Ex situ conservation, in contrast, conserves species outside their natural habitat (Cochrane et al. 2007). This approach is most appropriate where populations and/or plant numbers are small or threatened by disease and/or human activities or habitat change. Ex situ storage provides a resource that can be used for re-vegetation if in situ storage fails. The two approaches should, therefore, be regarded as complementary, with ex situ storage providing insurance against sudden loss of species in in situ storage (Cochrane et al. 2007). 
Seed preservation is one of the most commonly used methods of ex situ conservation (Theilade \& Petri 2003). Ex situ storage usually requires drying of seed to low moisture content (3-7\% fresh weight basis), depending on the species, and storage at low temperature, preferably at $-18^{\circ} \mathrm{C}$ or cooler. Temperature and moisture content of the seed are major factors in determining whether viability is retained in storage (Hong et al. 2001; Theilade \& Petri 2003). For many New Zealand threatened species, however, the information on seed biology, seed storage requirements and seed dormancy release mechanisms is either incomplete or unavailable.

Carmichaelia williamsii Kirk (Fabaceae) has a conservation assessment of "nationally endangered' based on its restricted distribution and small population size (Hitchmough et al. 2007). It is restricted to the northern offshore islands (particularly the Poor Knights Islands and the Aldermen Islands) and to two small remnant populations near East Cape. Some populations are at risk from coastal erosion. The species is principally pollinated by New Zealand honeyeaters. Loss of these pollinators will reduce seed production (Heenan 1996; Brandon et al. 2004; New Zealand Conservation Network 2005a; Hitchmough et al. 2007).

Clianthus puniceus (G. Don) Sol. ex Lindl. (Fabaceae) is cultivated widely, but wild populations are classified as 'nationally critical'. In 2005 only one naturally occurring plant population was known in the wild at a site near the Kaipara Harbour. At this site $C$. puniceus is threatened by summer droughts, browsing animals and competition from weeds (Shaw \& Burns 1997; New Zealand Conservation Network 2005b; Hitchmough et al. 2007).

Hibiscus diversifolius Jacq. (Malvaceae) appears restricted to the northern most extremity of the North Island (from about Reef Point and Doubtless Bay north) (New Zealand Conservation Network, 2005c). The largest populations are known to occur on the eastern side of the Te Paki dune wetland area. This species is classified as 'nationally vulnerable', and is under severe threat from browsing animals, particularly wild cattle and horses. Some populations at Tokerau Beach have been destroyed by coastal housing development (de Lange et al. 2004; New Zealand Conservation Network 2005c; Hitchmough et al. 2007).

In this study, experiments were conducted to determine the desiccation tolerance, dormancy status and germination of $C$. williamsii, $C$. puniceus and $H$. diversifolius seed.

\section{Methods \\ Seed material}

C. williamsii, $C$. puniceus and $H$. diversifolius seed pods were collected from the Auckland Botanic Gardens in 2007. The collected pods were couriered to Massey University (Manawatu Campus, Turitea Site) in paper bags within 12 days of collection (Table 1). The seeds were extracted from the pods by hand and the initial moisture content (MC) and germination determined.

\section{Determination of moisture content and germination}

The moisture content of the whole seed was determined using the low-constanttemperature oven method described in the International Rules for Seed Testing (ISTA, 2007). Four replicates of 10 (C. williamsii) or 25 seeds (C. puniceus and $H$. diversifolius) were cut in half and weighed before and after drying in a $103^{\circ} \mathrm{C} \pm 2^{\circ} \mathrm{C}$ oven for $17 \mathrm{~h}$. MC was calculated as the percentage of water on a fresh weight basis. Seed germination was determined using four replicates of 20 ( $C$. williamsii), 25 ( $H$. diversifolius) or 50 (C. puniceus) seeds. Seeds were placed between moist folded 38 lb regular weight seed germination paper (Anchor Paper Company, St. Paul, Minnesota) held in closed boxes and 
incubated at $20^{\circ} \mathrm{C}$. A seed was considered to have germinated when a normal seedling had developed; a seedling was classified as normal when it had a well developed primary root and intact hypocotyl and cotyledons (ISTA, 2007).

\section{Seed desiccation experiment}

Seed samples were dried to target MCs of $10 \%, 5 \%$ and $2.5 \%$. Seed from each sample was mixed with an equal weight of silica gel in polythene bags and placed in a desiccator and held at $20^{\circ} \mathrm{C}$. Seed samples were monitored daily for target weights. The target weight that corresponded to each target MC was calculated using the following formula (adapted from ISTA, 2007):

Weight of seed $(\mathrm{g})$ at target moisture content $=$

$\left(\frac{100-\mathrm{IMC}}{100-\mathrm{TMC}}\right) \times$ initial seed weight $(\mathrm{g})$

Where IMC $=$ initial seed moisture content

$\mathrm{TMC}=$ target seed moisture content

Once the target weight was reached seed $\mathrm{MC}$ and germination were determined as described above. To avoid imbibition damage of seed at $10 \%$ moisture content and below, seeds were humidified before germination by placing them above water in a closed container at $20^{\circ} \mathrm{C}$ for 24 hours (IPGRI-DFSC, 2004).

\section{Seed dormancy experiment}

Seeds that had not germinated after 3 weeks were counted and manually scarified with a scalpel by cutting the seed coat in the cotyledon area. Scarified seeds were returned to $20^{\circ} \mathrm{C}$ to continue the germination process for another 6 days after which ungerminated seeds were classified as viable when they showed no sign of infection and were firm when pressed. Normal seedlings were assessed as previously described.

\section{Data analysis}

Analysis of Variance (ANOVA) was conducted on sample means of each treatment. Where significant effects were detected in the ANOVA $(\mathrm{P}=0.05)$, means were compared using the LSD (Least Significant Difference) test. Prior to analysis, data were checked for normality. No transformations were necessary. SAS ${ }^{\circledR}$ for Windows (Release 9.13, SAS Institute, Cary, North Carolina) was used for analysis of all data.

\section{Results \\ Initial characteristics}

The initial characteristics of the seeds of the three species used in the experiments are shown in Table 1. The moisture content of C. williamsii and $C$. puniceus seeds on receipt was around $20 \%$ and germination over 95\%. In contrast, seeds of $H$. diversifolius had $12.4 \% \mathrm{MC}$ and low germination (46\%).

Table 1 Initial characteristics of Carmichaelia williamsii, Clianthus puniceus and Hibiscus diversifolius.

\begin{tabular}{llll}
\hline & C. williamsii & C. puniceus & H. diversifolius \\
\hline Collection date & $20 / 12 / 2007$ & $17 / 12 / 02007$ & $31 / 08 / 2007$ \\
Arrival date & $27 / 12 / 2007$ & $27 / 12 / 2007$ & $12 / 09 / 2007$ \\
Number of seeds prepared & 270 & 1920 & 660 \\
Seed weight $(\mathrm{mg} \pm$ S.E.) & $19.8 \pm 0.48$ & $22.4 \pm 0.32$ & $11.3 \pm 0.12$ \\
Initial moisture content (\%) & 19.2 & 22.8 & 12.4 \\
Germination (\%) & 98 & 94 & 46 \\
\hline
\end{tabular}




\section{Desiccation tolerance}

Seeds of $C$. williamsii, $C$. puniceus and $H$. diversifolius tolerated desiccation over silica gel to $2.9-3.7 \% \mathrm{MC}$ while maintaining their initial germination rate. C. williamsii seed germination of $96-98 \%$ was maintained as MC declined from $19.8 \%$ to $3.7 \%$ (Figure 1a). C. puniceus seeds tolerated desiccation to about $3.7 \% \mathrm{MC}$ without loss of initial germination (Figure 1b). H. diversifolius seed had poor initial germination $(46 \%)$, but germination did not decline further with desiccation to $2.9 \%$ (Figure 1c). For $H$. diversifolius the dead seed percentage at $12.4,10.8$ and $2.9 \% \mathrm{MC}$ was $50 \%, 37 \%$ and
$41 \%$, respectively.

\section{Seed dormancy}

The proportion of seeds of $C$. williamsii and $C$. puniceus having an impermeable seed coat increased as moisture content declined to $3.7 \%$ and $10.3 \%$, respectively. However, hardseedness in $C$. puniceus decreased markedly when seeds were then further dried to $3.7 \%$. Seeds with an impermeable seed coat required scarification for germination to proceed. After scarification, the germination percentage increased to $96-100 \%$ for all three species compared to $5-20 \%$ in control seeds (Table 2).

Table 2 Hardseededness percentages of fresh and after drying on silica gel and changes of germination of without scarification and after scarification of viable seeds of Carmichaelia williamsii, Clianthus puniceus and Hibiscus diversifolius.

\begin{tabular}{ccccc}
\hline $\begin{array}{c}\text { Drying time } \\
\text { (days) }\end{array}$ & $\begin{array}{c}\text { Moisture } \\
\text { content (\%) }\end{array}$ & Hardseededness $(\%)$ & \multicolumn{2}{c}{ Germination (\% of viable seeds) } \\
\hline C. williamsii & & & Without scarification & After scarification \\
0 & 19.8 & $3 \mathrm{~B}$ & $95 \mathrm{Aa}$ & $98 \mathrm{Aa}$ \\
5 & 8.4 & $86 \mathrm{~A}$ & $14 \mathrm{Bb}$ & $96 \mathrm{Aa}$ \\
35 & 3.7 & $82 \mathrm{~A}$ & $13 \mathrm{Bb}$ & $97 \mathrm{Aa}$ \\
C. puniceus & & & & \\
0 & 22.8 & $25 \mathrm{~B}$ & $73 \mathrm{Bb}$ & $96 \mathrm{Aa}$ \\
2 & 10.3 & $92 \mathrm{~A}$ & $5 \mathrm{Cb}$ & $96 \mathrm{Aa}$ \\
10 & 5.3 & $12 \mathrm{C}$ & $85 \mathrm{Ab}$ & $96 \mathrm{Aa}$ \\
35 & 3.7 & $9 \mathrm{C}$ & $84 \mathrm{Ab}$ & $96 \mathrm{Aa}$ \\
H. diversifolius & & & & \\
0 & 12.4 & $95 \mathrm{~A}$ & $5 \mathrm{Ab}$ & $100 \mathrm{Aa}$ \\
1 & 10.8 & $89 \mathrm{~A}$ & $11 \mathrm{Ab}$ & $97 \mathrm{Aa}$ \\
19 & 2.9 & $80 \mathrm{~A}$ & $20 \mathrm{Ab}$ & $98 \mathrm{Aa}$ \\
\hline
\end{tabular}

Numbers following the same uppercase letters are not significantly different within each species; numbers within rows sharing the same lowercase letters are not significantly different (LSD, $\mathrm{P}<0.05$ ) 

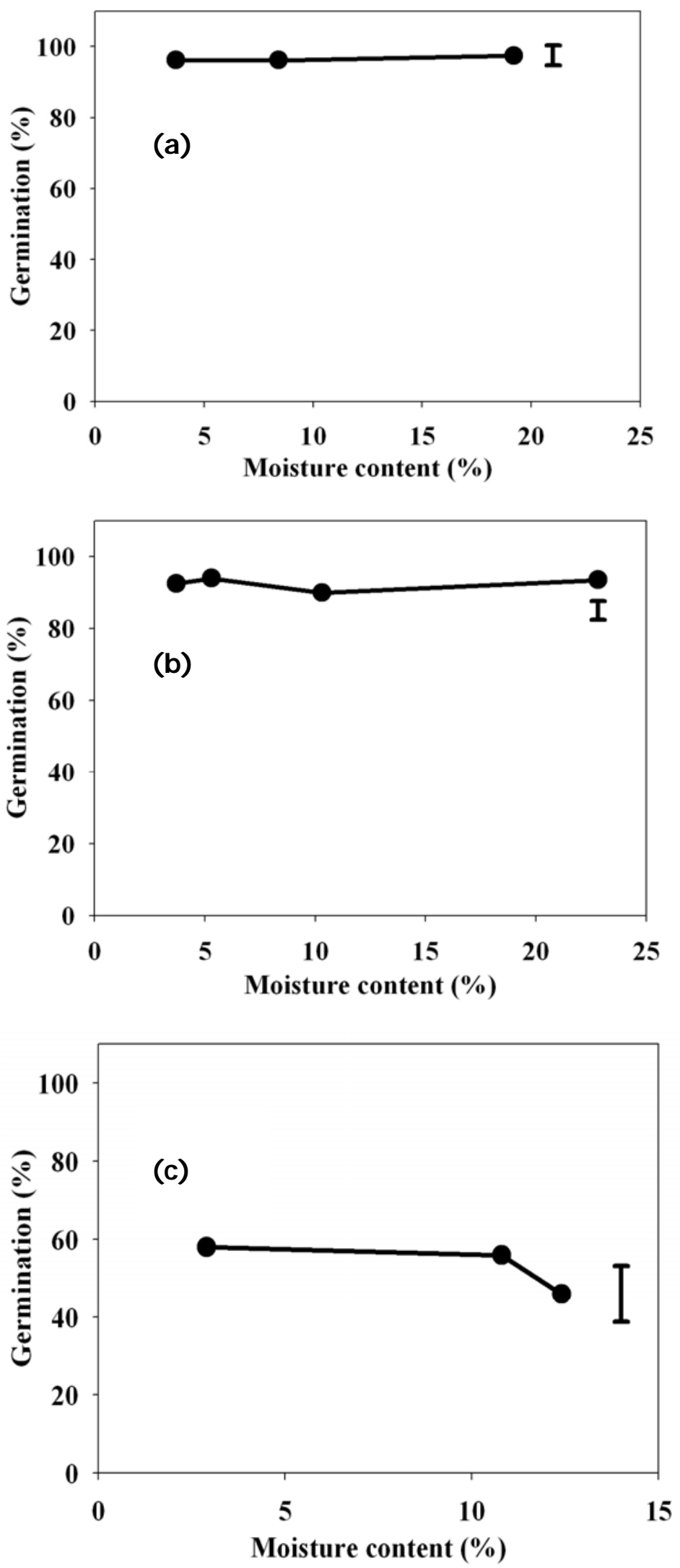

Figure 1 Germination capacity of seeds during desiccation: (a) C. williamsii, (b) C. puniceus, (c) H. diversifolius. Bars indicate LSD (0.05\%). 


\section{Discussion}

\section{Desiccation experiment}

Tolerance of seed desiccation is crucial in determining seed storage characteristics. Three categories of seed storage behaviour, orthodox, intermediate and recalcitrant have been identified based on seed desiccation tolerance, longevity and tolerance to low temperatures during storage (Yang et al. 2004). Long-term seed preservation for genetic conservation is possible only for species with orthodox seed storage behaviour (Hong et al. 2001; Berjak \& Pammenter, 2008). In such species seed longevity increases with decrease in storage moisture content (as low as 3-7\%) and temperature in a 'quantifiable and predictable way' (Hong \& Ellis, 1996; Hong et al. 2001; Yang et al. 2004).

Desiccation tolerance of $C$. williamsii, $C$. puniceus and $H$. diversifolius seeds in this investigation is typical of orthodox seed. The desiccation tolerance of $C$. williamsii and $C$. puniceus seeds is similar to that of other Fabaceae of which $97 \%$ have been classified as orthodox (Liu et al. 2008). For example, seeds of two tree species Bauhinia purpurea and Pongamia pinnata tolerate drying to moisture contents less than or equal to $5 \%$ without loss of viability (Isasi, 2003; Kumar et al. 2007). Seeds of other Hibiscus species such as $H$. cannabinus have been reported as desiccation tolerant. H. cannabinus retained high germination (86\%) at 7.2 and $1.1 \% \mathrm{MC}$ (Hu et al. 1998). Also this species retained $66 \%$ germination after 39.5 years storage at $-18^{\circ} \mathrm{C}$ indicating orthodox storage behaviour (Walters et al. 2005).

In this study, the germination percentage of $H$. diversifolius was low. Angelini et al. (1998) commented that low germination percentage $(40.8 \%)$ of $H$. cannabinus grown in central Italy was due to unfavourable temperature and moisture conditions during seed filling, resulting in rapid seed deterioration and increased seed coat susceptibility to fungal pathogens. This presence of fungi on dead $H$. diversifolius seed observed in this study may suggest a similar problem, but in the absence of data on reserve accumulation in the seed lot, this is speculative.

Seeds which tolerate desiccation to low moisture content do not necessarily show orthodox storage behaviour. For example, seeds of Anadenanthera colubrine (Fabaceae) tolerated desiccation to $4 \% \mathrm{MC}$ ( $98 \%$ germination), but retained only $20 \%$ germination after 23 months of hermetic storage at $-18^{\circ} \mathrm{C}$ and $4 \% \mathrm{MC}$ (Rojas Espinoza 2005). To confirm that the seed behaviour of the species studied here is orthodox retention of germination in storage at these low moisture contents and low temperature (for example $-18^{\circ} \mathrm{C}$ ) will need to be assessed.

\section{Seed dormancy}

The results of this study confirm that dormancy in $C$. puniceu, $C$. williamsii and $H$. diversifolius is a function of the seed coat preventing water uptake by the dry seed. Hardseedness is typical of many other species of Fabaceae and Malvaceae (MaiHong et al. 2003; Van Assche \& Vandelook 2006; Michael et al. 2007). For example, Shaw and Burns (1997), Gruner and Heenan (2001) and Westra et al. (1996) have reported the scarification is required for germination of C. puniceus, Carmichaelia spp. and Hibiscus trionum, respectively.

In species exhibiting hardseededness, water impermeability of the seed coat usually develops at moisture contents between 15\% and $54 \%$ during maturation drying of the seed (Michael et al. 2007). If seeds are removed from the plant after embryo maturity, but before any drying and impermeability can develop, seeds should be capable of germination (Mai-Hong et al. 2003; Usberti et al. 2006; Michael et al. 2007). This response has been observed in Fabaceae (Mai-Hong et al. 2003; Usberti et al. 2006) and was observed in the Fabaceae studied here where desiccation also caused an increase of impermeability in comparison to fresh seed. 
A water-impermeable seed coat has been suggested as a factor in the ability of seed of some species to survive long-term storage (e.g., Liparia villosa is reported to have survived for $>200$ years) (Daws et al. 2007). In many species of Fabaceae, the hilum acts as a one-way valve (Daws et al. 2007). This allows loss of water from the seed, but not uptake (Hyde, 1954). Consequently, the seed MC will equilibrate to that of the lowest relative humidity experienced by the seed and remain at that $\mathrm{MC}$ irrespective of whether higher ambient relative humidity is subsequently experienced. This ability to remain at low $\mathrm{MC}$ under high ambient relative humidity is likely to be a key factor in maximising long-term survival of these species (Daws et al. 2007). The effect, if any, of loss of water impermeability below $6 \% \mathrm{MC}$ in seed of C. puniceus on the longterm survival of seed in storage needs to be determined.

The mechanism by which drying to low seed moisture alleviates hardseedness in $C$. puniceus is not known. However, for many Fabaceae, treatments such as acid scarification, hot water, dry heat, and high or fluctuating temperature will alleviate hardseedness by inducing fractures in the lens, hilum, micropyle or seed coat (Zeng et al. 2005; $\mathrm{Hu}$ et al. 2008). Although there is no evidence that drying is involved in loss of impermeability in Fabaceae, dry storage or drying of hard seed can render the seed coat permeable in some species of Geraniaceae. For example, after drying exhumed seeds of Erodium and Geranium species for 7 days in a desiccator over silica gel, $88-100 \%$ of the seeds germinated in 1 or 2 days compared with $0-1 \%$ in un-dried seeds (Van Assche \& Vandelook, 2006). The current study showed a similar result for C. puniceus, where drying for a relatively short period $(10$ days) in silica gel increased seed coat permeability and, as a consequence, germination increased to $85 \%$.

The present study emphasises the importance of an understanding of the desiccation behaviour and dormancy mechanisms within the seed. At the collection MCs of $19.8 \%$ and $22.8 \%$ for $C$. williamsii and $C$. puniceus respectively hardseedness had not developed. Desiccation to MCs of $8.4 \%$ and $10.3 \%$ respectively induced hardseedness and resulted in low germination percentage (5$14 \%$ ). Failure to recognise the decline in germination with desiccation as being a function of the imposition of dormancy could lead to the erroneous conclusion that viability loss is associated with loss of moisture.

\section{Acknowledgements}

This work was supported by Massey University and through scholarship support from Education New Zealand and the Korea Seed \& Variety Service to the senior author. We thank Kerry Gillbanks, Auckland Botanic Gardens, for providing seeds.

\section{References}

Angelini, L.G.; Macchia, M.; Ceccarini, L.; Bonari, E. 1998. Screening of kenaf (Hibiscus cannabinus L.) genotypes for low temperature requirements during germination and evaluation of feasibility of seed production in Italy. Field Crops Research 59: 7379.

Berjak, P.; Pammenter, N.W. 2008. From Avicennia to Zizania: Seed recalcitrance in perspective. Annals of Botany 101: 213-228.

Brandon, A.; de Lange, P.; Townsend, A. 2004. Threatened plants of Waikato Conservancy. Department of Conservation, Wellington, New Zealand. 94 pp.

Cochrane, J.A.; Crawford, A.D.; Monks, L.T. 2007. The significance of ex situ seed conservation to reintroduction of threatened plants. Australian Journal of Botany 55: 356-361.

Daws, M.I.; Davies, J.; Vaes, E.; van Gelder, R.; Pritchard, H.W. 2007. Two- 
hundred-year seed survival of Leucospermum and two other woody species from the Cape Floristic region, South Africa. Seed Science Research 17: 73-79.

de Lange, P.J.; Norton, D.A.; Heenan, P.B.; Courtney, S.P.; Molloy, B.P.J.; Ogle, C.C.; Johnson, P.N.; Hitchmough, R. 2004. Threatened and uncommon plants of New Zealand. New Zealand Journal of Botany 42: 45-76.

Dopson, S.R.; de Lange, P.J.; Ogle, C.C.; Rance, B.D.; Courtney, S.P.; Molloy, J. 1999. The conservation requirements of New Zealand's nationally threatened vascular plants. Department of Conservation, Wellington, New Zealand. 194 pp.

Gruner, I.; Heenan, P.B. 2001. Viability and germination of seeds of Carmichaelia (Fabaceae) after prolonged storage. New Zealand Journal of Botany 39: 125-131.

Heenan, P.B. 1996. A taxonomic revision of Carmichaelia (Fabaceae-Galegeae) in New Zealand (part 2). New Zealand Journal of Botany 34: 157177.

Hitchmough, R.; Bull, L.; Cromarty, P. 2007. New Zealand threat classification system lists 2005 . Science \& Technical Publishing Department of Conservation, Wellington, New Zealand. 194 pp.

Hong, T.D.; Ahmad, N.B.; Murdoch, A.J. 2001. Optimum air-dry storage conditions for sweet orange (Citrus sinensis (L.) Osbeck) and lemon (Citrus limon (L.) Burm. f.) seeds. Seed Science and Technology 29: 183-192.

Hong, T.D.; Ellis, R.H. 1996. A protocol to determine seed storage behaviour. International Plant Genetic Resources Institute (IPGRI), Technical Bulletin No. 1, Rome, Italy. $61 \mathrm{pp}$.
Hu, X.R.; Zhang, Y.L.; Hu, C.L.; Tao, M.; Chen, S.P. 1998. A comparison of methods for drying seeds: vacuum freeze-drier versus silica gel. Seed Science Research 8: 29-33.

Hu, X.W.; Wang, Y.R.; Wu, Y.P.; Nan, Z.B.; Baskin, C.C. 2008. Role of the lens in physical dormancy in seeds of Sophora alopecuroides L. (Fabaceae) from north-west China. Australian Journal of Agricultural Research 59: 491-497.

Hyde, E.O.C. 1954. The function of the hilum in some Papilionaceae in relation to the ripening of the seed and the permeability of the testa. Annals of Botany 18: 241-256.

IPGRI-DFSC. 2004. The desiccation and storage protocol. pp. 345-351. In: Comparative storage biology of tropical tree seeds. Eds. Sacande, M.; Joker, D.; Dulloo, M.E.; Thomsen, K.A. International Plant Genetic Resources Institute (IPGRI), Rome, Italy.

Isasi, O. 2003. Tolerance to desiccation in Bauhinia purpurea seeds. Pastos y Forrajes 26: 297-301.

ISTA. 2007. International rules for seed testing. Edition 2007. The International Seed Testing Association, Bassersdorf, Switzerland.

Kumar, S.; Radhamani, J.; Singh, A.K.; Varaprasad, K.S. 2007. Germination and seed storage behaviour in Pongamia pinnata L. Current Science 93: 910-911.

Liu, K.; Eastwood, R.J.; Flynn, S.; Turner, R.M.; Stuppy, W.H. 2008. Seed Information Database (release 7.1, May 2008). Retrieved 23 June, 2008, from http://www.kew.org/data/sid

Mai-Hong, T.; Hong, T.D.; Hien, N.T.; Ellis, R.H. 2003. Onset of germinability, desiccation tolerance and hardseededness in developing seeds of Peltophorum pterocarpum (DC) 
K. Heyne (Caesalpinioideae). Seed Science Research 13: 323-327.

Michael, P.J.; Steadman, K.J.; Plummer, J.A. 2007. Seed development in Malva parviflora: Onset of germinability, dormancy and desiccation tolerance. Australian Journal of Experimental Agriculture 47: 683-688.

New Zealand Conservation Network 2005a. New Zealand's Threatened Plants \& Fungi. Retrieved 22 June, 2008, from http://www.nzpcn.org.nz/nz threaten edplants/detail.asp?PlantID $=61$

New Zealand Conservation Network 2005b. New Zealand's Threatened Plants \& Fungi. Retrieved 22 June, 2008, from http://www.nzpcn.org.nz/nz threaten edplants/detail.asp?PlantID $=13$

New Zealand Conservation Network 2005c. New Zealand's Threatened Plants \& Fungi. Retrieved 23 June, 2008, from http://www.nzpcn.org.nz/vascular_pl ants/detail.asp?PlantID $=112$

Rojas Espinoza, E. 2005. Desiccation and storage of Anadenanthera colubrina seeds. pp. 251-257. In: Comparative storage biology of tropical tree seeds. Eds. Sacande, M.; Joker, D.; Dulloo, M.E.; Thomsen, K.A. International Plant Genetic Resources Institute (IPGRI), Rome, Italy.

Shaw, W.B.; Burns, B.R. 1997. The ecology and conservation of the endangered endemic shrub, kowhai ngutukaka Clianthus puniceus in New Zealand. Biological Conservation 81: 233245.

Theilade, I.; Petri, L. 2003. Conservation of tropical trees ex situ through storage and use. Guidelines and Technical
Notes No. 65. Danida Forest Seed Centre, Humlebaek, Denmark. 19 pp. Usberti, R.; Roberts, E.H.; Ellis, R.H. 2006. Prediction of cottonseed longevity. Pesquisa Agropecuaria Brasileira 41: 1435-1441.

Van Assche, J.A.; Vandelook, F.E.A. 2006. Germination ecology of eleven species of Geraniaceae and Malvaceae, with special reference to the effects of drying seeds. Seed Science Research 16: 283-290.

Walters, C.; Wheeler, L.M.; Grotenhuis, J.M. 2005. Longevity of seeds stored in a genebank: species characteristics. Seed Science Research 15: 1-20.

Warmington, B.; Cole, G.; King, G. 1996. New Zealand: Country report to the FAO international technical conference on plant genetic resources. The National Authorities, Leipzig, Germany. 82 pp.

Westra, P.; Pearson, C.H.; Ristau, R.; Schweissing, F. 1996. Venice mallow (Hibiscus trionum) seed production and persistence in soil in Colorado. Weed Technology 10: 22-28.

Yang, Q.H.; Yin, S.H.; Song, S.Q.; Ye, W.H. 2004. Development of desiccation tolerance and germination physiology of Crotalaria pallida Ait. seeds. Seed Science and Technology 32: 99-111.

Zeng, L.W.; Cocks, P.S.; Kailis, S.G.; Kuo, J. 2005. The role of fractures and lipids in the seed coat in the loss of hardseededness of six Mediterranean legume species. Journal of Agricultural Science 143: 43-55. 